\title{
AS FORÇAS ARMADAS: Sua Relação com a Democracia e os Direitos Humanos
}

http://dx.doi.org/10.21527/2176-6622.2021.55.118-131

Recebido em: 20/8/2019

Modificações solicitadas em: 26/5/2020

Aceito em: 21/6/2020

Filipe Cortes de Menezes

Autor correspondente. Universidade Tiradentes - Unit. R. Lagarto, 236 - Centro. CEP 49010-390. Aracaju/SE, Brasil. http://lattes.cnpq.br/8678020645548454. https://orcid.org/0000-0002-0487-7614. filipe_cortes@yahoo.com.br

Fran Espinoza

Universidade Tiradentes - Unit. Aracaju/SE, Brasil.

\section{RESUMO}

O presente artigo tem por objetivo reinterpretar os postulados basilares das Forças Armadas (hierarquia e disciplina) de acordo com as principais noções de democracia e dos direitos humanos numa perspectiva crítica e contra-hegemônica. Para tanto, busca-se responder à seguinte pergunta: Qual o papel institucional das Forças Armadas em um regime democrático e sob uma perspectiva crítica de direitos humanos mediante análise da concepção acerca dos princípios da hierarquia e disciplina? A metodologia utilizada consistiu em um estudo qualitativo por meio de revisão bibliográfica dos conceitos de direitos humanos, democracia e sua relação com as Forças Armadas no Brasil, em especial na releitura das suas premissas básicas: hierarquia e disciplina. Com o artigo consegue-se sistematizar o significado de democracia, direitos humanos e, principalmente, relacioná-los com as Forças Armadas, permitindo uma nova perspectiva crítica de abordagem à instituição.

Palavras-chave: Brasil. Forças Armadas. Direitos humanos.

\section{THE ARMED FORCES: THEIR RELATIONSHIP WITH DEMOCRACY AND HUMAN RIGHTS}

\section{ABSTRACT}

This paper aims to reinterpret the basic postulates of the Armed Forces (hierarchy and discipline) according to the main democratic and human rights fundamentals in a critical and counter-hegemonic perspective. Thus, we seek to answer the following question: What is the institutional role of the Armed Forces in a democratic regime and under a critical perspective of human rights, by analysing the conception of the principles of hierarchy and discipline? The methodology used consisted of a qualitative study through a bibliographical review of the concepts of human rights, democracy and their relationship with the Armed Forces in Brazil, especially in the review of its basic premises: hierarchy and discipline. The paper makes it possible to systematize the meaning of democracy, human rights and, mainly, to relate them with the Armed Forces, allowing a new critical perspective to approach the institution.

Keywords: Brazil. Armed forces. Human rights.

\section{SUMÁRIO}

1 Introdução. 2 Desenvolvimento. 2.1 Democracia e direitos humanos. 2.2 Democracia e Forças Armadas. 2.3 Hierarquia, disciplina e direitos humanos no Brasil. 3 Conclusão. 4 Referências. 


\section{INTRODUÇÃO}

A análise do conceito de direitos humanos não pode ser instituída de forma desatrelada de um determinado contexto histórico, constituindo-se como uma realidade dinâmica, em constante alteração, pois decorre de um processo contínuo de lutas sociais. Seguem, no mesmo sentido, o estudo da democracia e a reflexão do papel das Forças Armadas neste regime, sobremodo contextualizadas numa perspectiva crítica de direitos humanos em consideração à realidade social e cultural do país.

Em decorrência desta diversidade e não obstante a variabilidade do conceito de democracia, de sorte a existir uma pluralidade de regimes correlatos, é possível a fixação de critérios mínimos de compreensão do que seja aquele regime, assim como direitos humanos, no prisma ora abordado.

Torna-se, assim, plenamente possível entender as Forças Armadas no Brasil por meio de suas características basilares, sua interação com a realidade política e social da nação, bem como por meio de uma reflexão sobre as premissas constitutivas dos direitos humanos, enquanto um processo permanente de luta por reconhecimento de pautas coletivas.

Dentre as características básicas da instituição em exame, ressaltam-se a hierarquia e a disciplina. No contexto do regime democrático, contudo, em especial naquele permeado por uma dinâmica de direitos humanos concretizadores das pautas coletivas dos grupos sociais, faz-se mister a sua ressignificação. Uma das bases do estudo crítico de direitos humanos e democracia é a necessária observância da dignidade das minorias e do reconhecimento das suas lutas sociais, que não podem ser invisibilizadas, esquecidas.

Desta forma, no presente artigo buscar-se-á, a partir de uma abordagem teórica do que seja democracia e direitos humanos com base nos principais aportes atinentes ao enfoque adotado por Fishkin (2015) e Honneth (2009), reinterpretar os postulados basilares das Forças Armadas (hierarquia e disciplina) de acordo com as principais noções de democracia e direitos humanos numa perspectiva crítica e contra-hegemônica, a fim de responder à seguinte pergunta: Qual o papel institucional das Forças Armadas em um regime democrático e sob uma perspectiva crítica de direitos humanos mediante revisão da concepção acerca dos princípios de hierarquia e disciplina?

Na primeira parte do trabalho serão fixadas as premissas do que sejam democracia e direitos humanos, compreendidos numa perspectiva crítica. Na segunda parte abordar-se-á a ligação entre democracia e Forças Armadas no Brasil. Na terceira parte cuidar-se-á da relação entre hierarquia, disciplina e direitos humanos no país. Por fim, serão apontados os principais resultados do trabalho.

A metodologia utilizada consistiu em um estudo qualitativo por meio de revisão bibliográfica dos conceitos de direitos humanos, democracia e sua relação com as Forças Armadas no Brasil, em especial na releitura das suas premissas base: hierarquia e disciplina. Entendidas sob um prisma clássico, a hierarquia e a disciplina têm relação de sujeição, autoridade, do superior sobre o inferior (MORGAN, 1996, p. 28), como postura de acatamento de ordem proferida por autoridade. No artigo busca-se adotar uma concepção diversa, à luz de uma perspectiva crítica e contra-hegemônica de democracia (DAHL, 2016; FISHKIN, 2015; LIJPHART, 2019) e direitos humanos (DUSSEL, 1995; HONNETH, 2009), de sorte a responder à problemática posta.

\section{DESENVOLVIMENTO}

\subsection{Democracia e direitos humanos}

Pluralidade, diversidade e contextualização são palavras-chave para se entender o fenômeno democrático, assim como a temática dos direitos da humanidade, aqui entendida sem qualquer ligação com gênero, etnia ou demais características individuais, compreendida, portanto, enquanto atrelada a determinado contexto histórico. O ser humano singular, dotado de peculiaridades, diferenças, características próprias, possui a aptidão natural de interação com os outros, processo no qual deve ocorrer um equilíbrio. Este, nas relações humanas, implica imperiosa necessidade de tratar o outro com igual respeito e consideração, o que importa em não violar o seu âmbito de proteção jurídica e social. 
A concepção do que seja democracia altera-se de forma dinâmica enquanto processo de afirmação de determinado povo, visando à garantia dos seus direitos essenciais, elementares e fundamentais, conquistados ao longo da história (SILVA, 2016, p. 128). Não se pode falar em apenas uma forma de democracia, mas sim em várias maneiras, modelos, de esta ser implementada, citando-se, exemplificativamente, o estudo que identificou pelo menos 36 tipos diversos de regime democrático (LIJPHART, 2019, p. 76).

Existem, contudo, algumas linhas delineadoras mínimas para se compreender um regime democrático, entendido como aquele que possibilita: a) participação real, efetiva; b) isonomia de voto; c) entendimento esclarecido; d) controle do planejamento; e) inclusão máxima de indivíduos. Estes critérios são relevantes a fim de que "(...) se os membros (por mais limitado que seja seu número) forem politicamente iguais para determinar as políticas da associação. Em outras palavras, quando qualquer das exigências é violada, os membros não serão politicamente iguais (...)" (DAHL, 2016, p. 50). Tais premissas permitem uma reflexão diferenciada sobre diversos regimes e formas de classificação, prismas de compreensão acerca do regime democrático. Neste contexto, por exemplo, insere-se a diferenciação entre democracia ideal e democracia procedimental.

A democracia procedimental pode ser entendida como aquela que define previamente as regras do jogo para os agentes sociais em conflito, ou seja, as regras de decisão bem como as instituições legitimadas para adotar a resolução das questões postas. Em outras palavras, entende-se tal democracia formal como “(...) caracterizada por um conjunto de regras (primárias ou fundamentais) que estabelecem quem está autorizado a tomar decisões coletivas e com quais procedimentos (...)" (BOBBIO, 2015, p. 35).

Sob o mesmo viés conceitual de democracia, isto é, aquela pautada num conjunto de regras preestabelecidas pelos agentes em disputa, podemos apontar, ainda, a seguinte conceituação:

A democracia política moderna é um sistema de governo no qual governantes são responsabilizados pelos cidadãos por suas ações na esfera pública, agindo diretamente por meio de competição e cooperação de seus representantes eleitos (DIAMOND, 2017, p. 31).

A democracia procedimental enaltece as instituições e o aparato burocrático estatal, em detrimento da atuação do indivíduo, membro da coletividade, que teria uma participação política mitigada.

Relacionada instrumentalmente à concepção anterior, apresenta-se a democracia representativa, uma vez que, por meio desta, o papel dos agentes políticos, integrantes da máquina política estatal, eleitos enquanto representantes do povo, é igualmente ressaltado. Cabe frisar, contudo, que, apesar da compreensão no contexto do tema democracia ter sido consolidada no regime estadunidense, a representação em si tem uma origem não democrática, tendo surgido na Idade Média (DAHL, 2016, p. 118-119).

Já a democracia, considerada por alguns como ideal, material, consistiria no cenário em que se garantisse efetivamente uma participação popular nas discussões das questões públicas, não sendo o aparato estatal, por meio dos agentes políticos, o principal ator da discussão, mas, sim, o próprio povo. Atrelado ao conceito de democracia ideal está, como percebido, o de participação, a qual deve ser executada de forma qualitativa, aspecto sobre o qual é pertinente a seguinte colocação:

Podemos falar sobre a qualidade de um processo deliberativo levando em consideração cinco condições: a) Informação: Até que ponto foi disponibilizado aos participantes o acesso a informações razoavelmente precisas que eles acreditam ser relevantes para o assunto; b) Equilíbrio substantivo: Até que ponto os argumentos de um ponto de vista são respondidos por pessoas que têm outro ponto de vista; c) Diversidade: Até que ponto as principais opiniões públicas são representadas por participantes na discussão; d) Consciência: Até que ponto os participantes ponderam o mérito dos argumentos; e) Consideração igualitária: Até que ponto os argumentos oferecidos por todos os participantes são considerados por seus méritos, independente de quais participantes os apresentaram (FISHKIN, 2015, p. 50).

Os defensores do modelo democrático representativo acreditam que os agentes políticos eleitos teriam melhores condições de deliberar e decidir as questões públicas, enquanto os partidários do regime participativo compreendem a imperiosa necessidade de o povo ser agente da discussão e não mero destinatário, uma vez que "(...) é o povo que precisará viver com a escolha das políticas. Ele precisa viver com os prós e contras. Por que não consultá-lo acerca das políticas com as quais ele terá que viver? (...)” (FISHKIN, 2015, p. 99). 
Desta forma, sobremodo no estudo das Forças Armadas, como se pontuará adiante, não se pode, de forma reducionista, limitar-se a uma compreensão do regime como aquele que submete os cidadãos a instituições pré-constituídas na forma de regras preestabelecidas, dentre os quais os integrantes daquelas forças; mesmo porque tais normas possuem um conteúdo dinâmico, influenciado por um contexto histórico, e não como uma entidade abstrata, estática e preconcebida.

O regime democrático, enquanto ambiente político de discussão no qual são resolvidos, de forma pacífica, os conflitos entre os diversos atores sociais mediante formulação de consensos temporários, possui o conflito como característica que lhe é ínsita:

Nesse ponto seguimos também a Marilena Chauí (1989; 1990; 2002; 2003), que com sua habitual lucidez argumenta que o conflito é o eixo central ou o coração do regime democrático. Para a filósofa brasileira, o traço principal que caracteriza a política, e em especial a política democrática, é precisamente a legitimidade e a necessidade do conflito (VITULLO, 2007, p. 59).

Como supracitado, a democracia pode ser apontada como o regime em que se permite a convivência pacífica entre diferentes visões de mundo, no qual o conflito, ínsito à divergência, é resolvido de forma pacífica, não violenta, por meio do diálogo, convencimento, respeito e consideração.

Os direitos humanos, da mesma maneira, não podem ser compreendidos como temática com um único significado, mas, sim, com múltiplos e diversos, atrelados à riqueza da história social, que reconhece as lutas sociais, respeitadora da dignidade do ser humano.

O respeito e a concretização da dignidade requerem a adoção de uma ética emancipatória dos direitos humanos por meio de uma transformação social, a fim de que cada pessoa exerça plenamente suas potencialidades, sem violação e discriminação; uma postura que entende no outro um ser merecedor de igual consideração e respeito.

Os direitos humanos não traduzem uma história linear, uma causa perdida, todavia_consistem num registro de combate, por meio de processos que consolidam locais de luta pela dignidade humana (PIOVESAN, 2017, p. 364).

Os direitos humanos não devem ser compreendidos na análise da temática contextual das Forças Armadas como um produto pronto, acabado e meramente internalizado, importado do exterior, mas, sim, fruto de um constante diálogo entre culturas díspares de vários povos, sem olvidar-se os dramas sociais de cada população e o histórico de exploração por que passaram especialmente os povos colonizados.

Os direitos humanos precisam ser enxergados, portanto, mediante uma análise crítica (contra-hegemônica) que reage a uma tentativa internacional, do mercado global, de imprimir uma versão hegemônica daqueles.

Em outras palavras, busca-se uma hermenêutica da libertação, que permite a um povo culturalmente dominado e explorado enxergar a realidade de forma diversa, não atrelada a uma visão externa considerada padrão, ditada, principalmente, por países detentores do poder financeiro global. Sobre tal forma de interpretação diversa, no estudo do contexto da América Latina verifica-se o seguinte posicionamento:

Em outras palavras, quando a filosofia de Ricoeur pareceria estar terminando o seu trabalho, só então começa o da filosofia da libertação. Suas perguntas são: Será que uma pessoa dominada terá condições de "interpretar" o "texto" produzido e interpretado 'dentro-do-mundo' do dominador? E, dentro de que condições subjetivas, objetivas e hermenêuticas, textuais etc. poderá ser realizada "adequadamente" essa interpretação? Para a autora Salazar Bondy, em sua obra Existe uma filosofia em América Latina? a resposta é a negativa: não é possível filosofar dentro de uma situação como esta! Mas para nós sim, que tomamos como ponto de partida uma Filosofia da Libertação, isso é possível, mas somente no caso de o leitor, intérprete ou filósofo estarem comprometidos com um processo prático de libertação: tudo isso resume, exatamente, o tema de uma filosofia e de uma ética de libertação (DUSSEL, 1995, p. 31). 
Por meio da forma supradestacada de compreensão dos direitos humanos, permite-se uma maior participação da população que, tomando consciência das suas necessidades, passa a assumir a responsabilidade pela resolução dos problemas coletivos, sentindo-se agente e não mera destinatária de direitos, não submissa, portanto, ao comando das instituições e elites, como as Forças Armadas, mas, ao revés, como fator influenciador e ressignificador destas.

Cuida-se de bem entender a relação de poder existente na sociedade, que não pode ter a acepção meramente destrutiva, de submissão, mas também ser considerado um fator construtivo. Este fator não é somente repressivo, mas igualmente constitui uma força que produz coisas, induz ao prazer, concretiza discursos, devendo ser "(...) como uma rede produtiva que atravessa todo o corpo social muito mais do que uma instância negativa que tem por função reprimir (...)" (FOUCAULT, 2018, p. 45).

Justamente por intermédio de um processo contínuo de reconhecimento de pautas coletivas, em especial por meio de lutas sociais, numa perspectiva crítica de direitos humanos que não se distancie do fator criativo e dinâmico da realidade social, deve-se analisar a luta social como resultante de uma pauta assumida por uma coletividade na qual as experiências individuais de respeito são assumidas por todo um grupo. Serve como força matriz a uma exigência pelo reconhecimento. Neste ponto

deve ser entendido por luta social no contexto de nossas considerações: trata-se do processo prático no qual as experiências individuais de desrespeito são interpretadas como experiências cruciais típicas de um grupo inteiro, de forma que elas podem influir, como motivos diretores da ação, na exigência coletiva por relações ampliadas de reconhecimento (HONNETH, 2009, p. 257).

No mesmo sentido, o direito constitucional, enquanto instrumento capaz de positivar as pautas de direitos humanos, seja em reconhecimento das lutas sociais dos grupos nacionais, seja como fruto de internalização de regras provindas do sistema internacional (no Brasil, por meio do artigo 5o, §§2o e 3으, da Constituição de 1988), numa perspectiva crítica de diálogo entre os povos, deve ser compreendido não como um fim da discussão, mas apenas como um dos fatores.

É essencial, ainda, destacar a importância do equilíbrio entre o Estado de direito e a democracia, pois o excesso desta não pode enfraquecer aquele e vice-versa. Há também uma relação entre o Direito e a Política, não estando os procedimentos constitucionais aptos a impedir esta relação (NEVES, 2009. p. 76).

Ademais, conceitos como democracia e direitos mantêm uma relação intrínseca. A existência dos direitos humanos pressupõe a da democracia, sendo esta o regime mais compatível com a proteção daqueles. Atualmente, 140 Estados-Nação realizam eleições periódicas, entretanto apenas 82 são considerados plenamente democráticos (57\% da população mundial), e em 1985 essa era a realidade em somente 44 Estados (38\%). Um regime democrático precisa ser "(...) baseado em eleições limpas e institucionalizadas (...)" (O'DONNELL, 2013, p. 28).

Traçadas estas noções preliminares de democracia e direitos humanos, passemos a discorrer agora sobre a relação entre aquele regime e as Forças Armadas no Brasil, para, em seguida, principiar-se a análise dos fatores basilares de hierarquia, disciplina e os direitos humanos no país.

\subsection{Democracia e Forças Armadas}

O regime democrático, como abordado no item anterior, possui vários modelos e formas de efetivação, não se podendo cogitar uma aplicação preconcebida-estática, e, sim, um sistema dinâmico que interage com a realidade histórica, social e econômica de determinada nação.

Esta acepção histórica leva em consideração justamente os fatores efetivos, reais, que influenciam na sua configuração e consolidação em determinado país; igual premissa a se adotar na análise da norma constitucional, por meio da qual se internaliza ou formaliza o reconhecimento de direitos humanos, assim como são expressas as diretrizes básicas da democracia e o funcionamento das suas instituições, dentre as quais as Forças Armadas.

A Constituição Federal apresenta-se como elemento de consolidação das normas políticas e jurídicas que regem determinada sociedade, um documento limitador e norteador das condutas dos gestores do poder. 
Por meio da norma constitucional, os princípios e valores basilares de uma nação são estabelecidos como resultados do consenso máximo no jogo da discussão política, ainda que não destoem do caráter provisório destes, o que é demonstrado, no caso da Carta Política, pela possibilidade de alterações por intermédio de Emendas.

Neste ponto, considerando a importância e o impacto da constituição de determinada nação, convém analisar como certo documento político-jurídico é elaborado, e, principalmente, ter consciência acerca das forças que concretizam as balizas nele consignadas. Tal visão há muito foi observada pela doutrina:

Os problemas constitucionais não são problemas de direito, mas do poder; a verdadeira Constituição de um país somente tem por base os fatores reais e efetivos do poder que naquele país vigem e as constituições escritas não têm valor nem são duráveis a não ser que exprimam fielmente os fatores do poder que imperam na realidade social; eis aí os critérios fundamentais que devemos sempre lembrar (...) (LASSALLE, 2016, p. 45).

A adequada análise constitucional e, consequentemente, de determinado sistema jurídico não deve se ater a uma verificação exclusivamente formal, técnico-jurídica, sendo igualmente relevante identificar os fatores reais de poder que influenciam na elaboração e concretização dos valores balizadores de determinada sociedade, sobretudo os positivados na constituição.

Os fatores reais de poder, assim, são as instituições e grupos sociais que têm influência sobre as condutas da sociedade, de forma direta ou por meio dos representantes eleitos de determinada nação. Neste ponto, o presente artigo aborda o exército como integrante das Forças Armadas na análise histórica da república brasileira e da democracia, um dos fatores determinantes na delimitação do seu perfil e do sistema democrático.

As Forças Armadas, desde a proclamação da República, e sob uma visão de retrospectiva nacional, apresentam-se como instituição que sempre esteve próxima ao poder, notadamente da gestão do chefe da administração pública, ora viabilizando, como no caso da própria proclamação da República e dos primeiros gestores militares, ora participando de golpes, como no Estado Novo em favor do chefe do poder, ora ainda o fazendo contra o gestor, no caso da destituição de Vargas em outubro de 1945 e em 1964 contra João Goulart.

A mencionada instituição castrense, neste ponto, nunca deixou de possuir alguma relação de proximidade com a política, sempre influenciando-a em alguma medida. Inclusive, como mais bem se pontuará doravante, dentro da própria instituição correntes formaram-se na discussão dos temas nacionais, com a existência, em determinado momento, dos ditos de "esquerda" e de "direita". Com efeito:

Revoltas militares aconteceram em todo o período da República Velha, aliás, a República em si é fruto de um golpe militar, mas já encontrava entre as instituições armadas um leque de influências políticas, à esquerda e à direita, conquanto esses conceitos não fossem operacionalizados como entendemos contemporaneamente no pensamento político (BARBOSA, 2018, p. 25).

O exército, na análise da história republicana brasileira, estaria inserido como um dos fatores que determinaram a organização do Estado ao longo do século 20. A instituição castrense, por exemplo, esteve na gestão da presidência da República por quase cinco décadas, abrangendo dois momentos de regime autocrático-totalitário: um no Estado-novo e outro na ditadura iniciada em 1964.

A proclamação da República contou com a intensa e decisiva participação dos membros das Forças Armadas, por meio de movimento organizado pelos comandantes sob a liderança do marechal Deodoro da Fonseca e com forte atuação política dos militares.

No Brasil, ao contrário de outros países, a República, oficializada em 1889, não foi conquistada pela população por meio de movimento revolucionário naquele momento temporal, originando-se de instituições e acordos das elites, dentre as quais o exército. 
Pode-se compreender a República brasileira, assim, enquanto consequência da reorganização das forças dirigentes da nação, e não como decorrente de uma consciência coletiva acerca das questões nacionais. $O$ Decreto $\mathrm{n}$ 0 01 de 15 de novembro de 1889, apesar disso, traz expressa, no seu artigo 701 , a previsão de superveniente manifestação popular, o que somente veio a ocorrer em 21 de abril de 1993 por força da Emenda Constitucional no 02/1992, no artigo 2으 do Ato das disposições Constitucionais Transitórias da atual Carta Política.

A influência da instituição castrense na República prosseguiu com a realização de diversos movimentos políticos e históricos nos países envolvendo militares ou ex-militares. A exemplo disto, podemos citar os movimentos tenentistas e constitucionalistas bem como o Estado novo, a primeira ditadura do país.

A atuação das corporações militares se deu também com a participação de diversos membros do exército em pleitos eleitorais para a presidência. Ou, ainda, com a participação direta em movimentos sociais, como o movimento tenentista e a intentona comunista, os quais tiveram militares ou ex-militares envolvidos, podendo-se citar Luiz Carlos Prestes como exemplo emblemático e apontar ainda o seu maior opositor, Getúlio Vargas, igualmente ex-militar.

O ser humano, enquanto ser social, necessita de interação com os demais membros da coletividade, a fim de melhor desenvolver sua personalidade, bem como contribuir no desenvolvimento do grupo a que pertence. $O$ soldado, enquanto pessoa cidadã, está naturalmente no seio de um corpo coletivo, com o qual interage, não se podendo exigir uma postura que lhe seja totalmente apolítica, sendo importante, sobretudo no contexto democrático, permitir-lhe uma postura cidadã.

A noção de vida ativa, ou melhor vita activa, inclusive no exercício da adequada e crítica cidadania, perpassa pelo reconhecimento e assunção desta obrigação geral do indivíduo perante o corpo social no qual se encontra inserido. Neste sentido, a filósofa Hannah Arendt (2017) muito bem observa que a qualidade da ação é a única atividade humana condicionada à vida em sociedade (p. 27).

A participação ativa de membros das forças armadas na vida política brasileira teve, por consequências inerentes, a diversidade de posições ideológicas também dentro da instituição, com a existência de grupos com posições por vezes antagônicas.

O grupo militar considerado "conservador", de "Direita", era organizado numa linha liberal, alinhada com os Estados Unidos, nominada por alguns como "entreguistas". Neste alinhamento foram feitos acordos de abertura com o mercado Americano, e a Política Brasileira deveria estar alinhada com o mesmo.

Neste grupo estiveram oficiais da Força Expedicionária Brasileira (FEB), que tiveram treinamento naquele país estrangeiro e ajudaram a fundar a Escola Superior de Guerra (ESG) e a Academia das Agulhas Negras. Acerca da relação entre parte das Forças Armadas e aquele país estrangeiro, expõe-se:

A aproximação ideológica entre militares brasileiros e empresários se expressou, por exemplo, no acordo militar de 1952 entre o Brasil e os Estados Unidos, tão criticado pelos nacionalistas do Clube militar. O objetivo acordado era encorajar a eliminação de barreiras e proporcionar incentivos para um aumento constante na participação da empresa privada no desenvolvimento dos recursos dos países estrangeiros e desencorajar, na medida do possível, a prática do monopólio e de cartelização (BARBOSA, 2018, p. 95).

Tal grupo militar acabou prevalecendo na instituição, em especial após a renúncia de Jânio Quadros, tendo, dentre suas pautas, o "Combate ao Comunismo", e participando efetivamente da instauração da Ditadura em 1964, tendo como um de seus representantes o então general Humberto de Alencar Castello Branco.

Com o início da ditadura, os militares considerados de "esquerda" foram perseguidos pelo regime e exonerados da instituição. $O$ contexto da história militar demonstra a existência de uma visão, por vezes, ideológica da corporação, ideia repetidamente refutada pelas Forças Armadas. Inclusive alguns levantes internos na própria caserna põem em reflexão o alcance dos institutos de hierarquia e disciplina. Sobre este ponto, tem-se

\footnotetext{
${ }^{1}$ Eis a redação do artigo 7o do Decreto 01, de 15 de novembro de 1889: “(...) Art. 7o. Sendo a Republica Federativa Brazileira a fórma de governo proclamada, o Governo Provisorio não reconhece nem reconhecerá nenhum governo local contrário á fórma republicana, aguardando, como lhe cumpre, o pronunciamento definitivo do voto da nação, livremente expressado pelo suffragio popular (...)". Disponível em: https://www2.camara.leg.br/legin/fed/decret/1824-1899/decreto-1-15-novembro-1889-532625-publicacaooriginal-14906-pe.html. Acesso em: 11 ago. 2019.
} 
A dissolução dos partidos políticos em 1937 e o fechamento político operado pelo regime impediram que a evolução da sociedade política acompanhasse o desenvolvimentismo. Mesmo dentro da corporação militar, que estava se reestruturando, conforme vimos, o período de 1930-1945 foi abalado por inúmeras revoltas contestadoras, todas com envolvimento de oficiais de primeiro ou segundo escalão: revolução constitucionalista de 1932; revolta comunista de 1935; putsch integralista de 1938; e inúmeras outras sedições de menor repercussão, não obstante, importantes. O expressivo número de incidentes leva José Murilo de Carvalho a caracterizar as Forças Armadas do período como "indisciplinada" e "profundamente dividida". Isso não impediu, entretanto, que o Exército como instituição participasse do golpe, que instituiu o Estado Novo. Na verdade, Góes Monteiro e Eurico Gaspar Dutra foram figuras centrais do golpe que mostrou, apesar de tudo, que o Exército já alcançara um grau de coesão interna que permitia uma intervenção na sociedade como todo (BARBOSA, 2018, p. 77).

A divergência interna, sobremodo o exercício do direito de discordância por grupos da instituição militar, que, como dito anteriormente, foram perseguidos e punidos pela ala conservadora após a sua assunção ao poder em 1964, demonstra o exercício do direito de resistência pelo reconhecimento da efetivação de determinada pauta política, que se opunha a uma pretensa hegemonia de pensamento e manifestação na instituição. Aliás, a ala conservadora, que defendia a postura intervencionista militar a serviço da ordem, de autoria do general Góis Monteiro, tinha por objetivo eliminar a política dentro do exército. Neste sentido, Carvalho (2019) faz a seguinte colocação:

Como se sabe, o projeto das Forças Armadas intervencionistas a serviço da ordem vem da década de 1930 e é de autoria do general Góis Monteiro. A doutrina Góis previa a eliminação da política dentro das Forças Armadas para que pudessem agir mais eficazmente como ator político. Em consequência, o Exército foi expurgado de divergentes e submetido a intensa doutrinação. Previa ainda a tutela sobre as forças políticas civis e uma política de industrialização baseada na iniciativa estatal. O Estado Novo concretizou os planos de Góis. Depois de 1964, um esforço semelhante foi desenvolvido. Novos expurgos e novo esforço de doutrinação, agora calcado na doutrina da Escola Superior de Guerra (ESG), o Góis coletivo (p. 208-209).

O direito de pensar, manifestar-se e expressar-se, sobretudo após a redemocratização, torna imperiosa a reflexão sobre a necessidade de respeito à divergência não somente no seio da sociedade, mas também internamente na instituição. Neste ponto, diversos debates ocorreram dentro do clube militar, como ressalta o seguinte estudo:

Para avaliar a unidade, a coerência e, finalmente, a divisão ideológica das Forças Armadas, acompanhamos a evolução da temperatura política do Clube Militar entre 1944 e 1964, através do registro dos debates, do teor das suas publicações e do resultado das suas eleições nessas décadas (BARBOSA, 2018, p. 80).

Durante o período ditatorial, iniciado em 1964, a instituição esteve a atender uma visão imperialista, de interesse internacional, constituindo o Clube Militar um espaço democrático interna corporis, de discussões internas, até mesmo para apresentação de posições por vezes divergentes entre os seus membros acerca das temáticas atinentes ao interesse nacional. Com respeito ao Clube militar, são pertinentes os seguintes apontamentos:

Nas etapas da ditadura pretoriana e do consulado militar, as Forças Armadas foram colocadas, pela ação de suas cúpulas, na posição de atender obrigatoriamente às pressões imperialistas, considerando-se essa posição como um dever delas, imposto a todas as organizações militares que perderiam, assim, o seu caráter nacional. Sem formas outras de organização, as questões pendentes tenderiam, nos meios militares, a gravitar, naturalmente, para as associações de classe, única área onde poderiam ser ainda discutidas e onde, para a discussão, não pesaria o favor hierárquico (SODRÉ, 2010, p. 373).

Ainda no que se refere à "divisão"2 ideológica, de posição política interna, que permeou o exército ao longo da história republicana, julga-se como apropriada a seguinte abordagem científica que refletiu sobre a época da Constituinte de 1988:

\footnotetext{
2 A expressão "divisão ideológica" é abordada no presente trabalho não como uma característica negativa, mas como uma qualidade ínsita a toda atividade humana política, como consequência correlata natural da pluralidade de posições diversas, solucionadas num regime democrático mediante o diálogo entre os agentes envolvidos.
} 


\begin{abstract}
A abertura de 1945 reintroduziu nas Forças Armadas as divisões políticas que tanto preocupavam o general Góis. O conflito aprofundou-se com o agravamento da crise política nacional, até que em 1964 o grosso do oficialato aderiu à intervenção, certamente mais por preocupação com a sobrevivência da organização do que por concordância com os argumentos dos golpistas. A grande pergunta hoje - e é uma pergunta não apenas teórica, mas também de grande relevância prática - é se há probabilidade de repetição do fracionamento das Forças Armadas como se deu no pós-1945. Mais importante ainda, se esse fracionamento, se a divisão política das Forças Armadas, é hoje desejável do ponto de vista da consolidação da democracia. $\mathrm{O}$ argumento em favor da politização, defendido por muitos, inclusive por militares vítimas dos expurgos, postula que, só pela penetração nas Forças Armadas dos conflitos ideológicos e políticos da sociedade será possível neutralizar as tendências antidemocráticas que nelas têm predominado, e fazê-las mais sensíveis aos problemas sociais. Os que defendem essa posição parecem crer mesmo na possibilidade de democratização do próprio aparelho militar ao fazer dele como que um espelho da sociedade. Vejo nessa postura reminiscência da tradição positivista republicana que insistia em ver no militar o soldado-cidadão. Essa tradição ganhou vida nova nos anos 1930, quando se fundiu com a esquerda do tenentismo, e teve seus momentos de glória na década de 1950 nas memoráveis lutas do Clube Militar. Não foi por acaso que Góis Monteiro combateu a influência positivista e que o governo militar procurou por todos os meios evitar divisões internas, mesmo quando expressadas no Clube militar (CARVALHO, 2019, p. 209-210).
\end{abstract}

A história do mencionado clube, um espaço de discussão política interna da caserna, com dirigentes eleitos pelos membros das Forças Armadas associadas no período de 1944 a 1964, divide-se em quatro fases.

Na primeira (1944-1952) o grupo teve como líderes oficiais nacionalistas com caráter esquerdista e progressista das Forças Armadas, tanto que a revista interna, na qual eram divulgadas manifestações, estava empenhada na Campanha de defesa do Monopólio da exploração do petróleo, da indústria nacional de automóveis e da proteção da borracha.

Na segunda fase (1952-1955) o mencionado Clube foi controlado pelo grupo militar de direita, e, mesmo a vitória da campanha $O$ petróleo é nosso, com a criação da Petrobras, não evitou a ascensão do dito grupo ao poder.

A terceira fase (1956-1961) iniciou-se com o nominado "golpe preventivo" do general Loot, em 11 de novembro de 1955, visando a garantir a posse de Juscelino Kubitschek.

Já a quarta fase (1961-1964) teve início com a vitória de Jânio Quadros, posto que, “(...) sob o pretexto de um telegrama enviado a Jânio pela diretoria, o Ministro de Guerra Odílio Dennys mandou prender esses oficiais. O resultado foi uma depuração administrativa (...)" (BARBOSA, 2018, p. 81-86).

A política, assim, nunca esteve alheia, ausente, da história das Forças Armadas, em especial do exército, de sorte que é historicamente equivocada a noção de que os miliares seriam apolíticos ou que não participariam da política. Sobre este aspecto, faz-se a seguinte colocação:

Como demonstrado em outros trabalhos (SEIDL, 2002; 2008), a participação direta ou indireta de oficiais do Exército no universo da política - seja em partidos, movimentos ou apenas através de ligações pessoais mais ou menos explícitas com agentes detentores de recursos políticos -, constituiu traço estruturante da carreira de oficial militar até as primeiras décadas da República ao ocupar espaço importante nas engrenagens de regulação da ascensão na hierarquia. Se desde o período colonial até pelo menos o final do Império fora bastante significativa a presença de oficiais graduados na ocupação de altos cargos políticos (deputado, senador, ministro, presidente de província) e da burocracia administrativa, a redução conhecida nas primeiras décadas seguintes não traduziu propriamente uma diminuição na intensidade daquele tipo de envolvimento, mas uma mudança em sua forma. O surgimento dos movimentos republicanista e abolicionista que marcariam as últimas décadas do regime imperial seria largamente incorporado pelo ideário de boa parte do oficialato do Exército brasileiro, o qual após seu último grande conflito no Paraguai desenvolvera maior sentimento de unidade corporativa, de sua importância para o país e ao mesmo tempo de frustração frente ao bacharelismo civil (SCHULZ, 1971, p. 252) (SEIDL, 2010, p. 84).

Os fundamentos basilares da democracia e direitos humanos apontados, assim como os registros históricos que demonstram a participação efetiva do exército na história republicana brasileira, seguem algumas reflexões decorrentes da relação entre os temas. 
Assim, cabe o questionamento: Qual tipo de democracia as Forças Armadas, em especial o exército, nos períodos em que não estiveram à frente de regimes autocráticos (com exclusão, portanto do Estado Novo e da ditadura de 1964), contribuíram para desenvolver no Brasil: procedimental (formal) ou ideal (material), representativa ou participativa?

De igual maneira, deve-se pensar: Com qual concepção de direitos humanos relaciona-se a atividade política na história militar brasileira? Uma visão hegemônica atrelada a uma visão das elites e conservadora ou contra-hegemônica?

Para alguns aspectos das questões supra iremos, ao final deste item, apresentar uma proposta de início ${ }^{3}$ de reflexão, e, no que se refere aos demais, procuraremos apontar a ponderação na parte do trabalho a seguir iniciada.

Como se percebe no registro histórico desenvolvido, não foi em todo o período republicano que as Forças Armadas, em especial o exército, estiveram à frente de regimes autocráticos, posto que em considerável parcela constituíram garantias da própria democracia ainda incipiente.

No início da República, sob o auspício da Constituição Brasileira de 1891, as Forças Armadas estavam a serviço da defesa dos poderes e instituições constitucionais, o que foi mantido na carta política de 1946. Com a Constituinte de 1988, após o período não democrático (1964-1985), a instituição castrense voltou a ter esta atribuição, não limitada à função de garantidora da lei da ordem, mas enaltecendo-se a função de defesa da soberania nacional e dos poderes constitucionais (CARVALHO, 2019, p. 207).

Desta forma, percebe-se que, seja antes de 1964 ou mesmo depois com a redemocratização de 1988, as Forças Armadas, nos períodos democráticos, tiveram suas atribuições atreladas à defesa de instituições, do aparato burocrático estatal, de regras preestabelecidas; enfim de uma concepção de democracia procedimental, formal, com viés tradicional e de manutenção de um sistema posto da visão das elites dominantes, e, consequentemente, também, de uma visão hegemônica ${ }^{4}$, estadunidense, importada, de direitos humanos.

A posição aqui sustentada decorre da análise da própria formação da república e do início de uma primeira fase incipiente da democracia brasileira, quando, pelo Decreto 1ํ, de 15 de novembro de 1889, no seu artigo 7으, estava prevista superveniente consulta popular sobre a instituição do novo regime, o que somente veio a ocorrer em 1993 por força de plebiscito, já no advento da Constituição de 1988.

A participação popular ampla e plural, descrita como democracia participativa, não encontrou respaldo na história brasileira, em especial relacionada à atuação militar. O golpe de 1964, aliás, decorreu do temor às nominadas reformas de base ${ }^{5}$. Outro argumento consistiu no próprio conservadorismo apontado nas discussões internas, sobretudo no Clube Militar, com a perseguição, nos anos que imediatamente antecedem aquela ditadura, aos ditos militares de "esquerda".

\footnotetext{
Não faz parte da proposta deste breve artigo exaurir a discussão temática, mas, ao revés, oportunizar premissas iniciais ao seu debate pela comunidade científica.

4 Para o foco abordado neste trabalho, adota-se, como visão hegemônica de democracia, a baseada no modelo estadunidense, bem como de direitos humanos, a que decorre deste modelo e busca apenas se ater a uma perspectiva primordialmente normativa e de reprodução acrítica de regras internacionais, sobretudo com igual influência de países política e economicamente influentes, como os Estados Unidos. Já na visão contra-hegemônica, predomina uma percepção crítica de direitos humanos, atrelados às lutas sociais por pautas coletivas, em reconhecimento de desigualdades existentes provenientes de realidades sociais díspares de cada país, decorrentes, sobremodo, de relações de exploração e resistência.

Manifestando-se na linha apresentada do artigo de que o golpe de 1964 teria decorrido, dentre outros pontos, do temor das reformas estruturais, conhecidas como "reformas de base", cabem as seguintes colocações: "(...) Os seguintes autores são muito representativos das análises que identificam o golpe político de 1964 como preventivo. São eles, o sociólogo Florestan Fernandes e os historiadores Caio Navarro de Toledo, Lucilia de Almeida Neves Delgado e Jacob Gorender. Suas ideias convergem quanto ao entendimento de que a principal motivação do golpe que depôs o governo constitucional, empossado em 1961, foi consequente de forte descontentamento de setores conservadores da política brasileira com a crescente e autônoma organização da sociedade civil naquela conjuntura. A destituição do presidente da República, bem como o afastamento compulsivo de seus aliados da vida pública nacional, segundo seu entendimento, objetivou evitar potenciais e profundas modificações na estrutura econômica e política do Brasil. O caráter transformador das reformas estruturais, reivindicadas pelo movimento social, não foi assimilado nem pelos setores tradicionais da sociedade brasileira, vinculados à propriedade latifundiária, nem pelos modernos representantes de um modelo capitalista industrializado e internacionalizado. As análises desses autores mesclam horizontes da longa duração com motivações conjunturais e enfatizam que os militares e civis que depuseram João Goulart agiram impulsionados por uma perspectiva preventiva. Isso porque o projeto de reformas de base, inclusive os da reforma agrária e do controle da remessa de lucros, ensejou nos setores conservadores o temor de uma revolução social. Essa convicção e temor de que o Brasil poderia adotar um modelo distributivo ou até mesmo, de acordo com Florestan Fernandes, caminhar em direção ao socialismo levou-os a se organizarem para pôr fim ao governo Jango (...)" (DELGADO, 2010, p. 132).
} 
De igual forma, a perspectiva sobre direitos humanos adotada no regime democrático brasileiro, nomeadamente no período anterior à carta política vigente, possui um viés hegemônico, precipuamente normativista, reprodutora de uma visão de mundo, como a estadunidense, típica de países política e economicamente influentes. Uma visão que olvida, ou ao menos não considera como fator principal, as relações de exploração e de desigualdade de uma maioria socialmente excluída.

Passemos agora a discorrer sobre as consequências e demais aspectos relacionados nesta discussão no que diz respeito à principiologia, base das Forças Armadas (hierarquia e disciplina), e em que medida a adoção de uma visão diferente de democracia e direitos humanos pode permitir uma ressignificação destes postulados e da própria instituição e, assim, possibilitar um diálogo das entidades militares com estes temas.

\subsection{Hierarquia, disciplina e direitos humanos no Brasil}

Conforme debatido no presente trabalho, uma perspectiva puramente hegemônica, que se limite a manter um status quo, em acordo com elites políticas locais, com a reprodução de normas e modelos estrangeiros, principalmente do regime estadunidense, não garantiu na história democrática brasileira uma participação popular efetiva na política. Ao contrário, afastou a maioria da população das decisões políticas, esta inclusive que somente veio a se manifestar sobre a forma republicana em 1993, quase cem anos após a sua instituição no país, por intermédio de uma constituição que copiava ${ }^{6}$, até no nome, o país do hemisfério norte.

Considerando a principiologia da atual constituição que veio adotar ${ }^{7}$ um regime misto, de representação e participação popular, bem como pautado nos direitos humanos, assim como em reconhecimento da realidade histórica das relações de exploração na sociedade brasileira, não sendo as Forças Armadas um agente externo a esta, é necessário fazer uma ressignificação da sua missão institucional, especialmente dos seus princípios basilares de hierarquia e disciplina.

Estes princípios são entendidos num prisma clássico enquanto relação de sujeição, autoridade, do superior sobre o inferior, no sentido do topo para a base, enquanto cadeia usada como canal de comunicação e decisão (MORGAN, 1996, p. 28). Na mesma linha, a legislação militar brasileira define:

A hierarquia militar é a ordenação da autoridade em níveis diferentes, dentro da estrutura das Forças Armadas. A ordenação se faz por postos ou graduações: dentro de um mesmo posto ou graduação se faz pela antiguidade no posto ou graduação. $O$ respeito à hierarquia é consubstanciado no espírito de acatamento à sequência de autoridade (BRASIL, 1980).

Uma mudança de prisma necessita ocorrer, sem, contudo, esquecer-se as dificuldades para tanto, decorrentes do conservadorismo inerente às Forças Armadas. Sobre este ponto, é pertinente a seguinte colocação:

A redemocratização advinda da constituição de 1988, mesmo com restrições, conferiu aos militares alguma possibilidade de manifestação; e despeito de seu perfil reconhecidamente conservador, o dado positivo é a afirmação de um compromisso com a democracia. Ao mesmo tempo, com ela emergem novos movimentos entre os militares e nos PMs, recolocando na agenda política a questão da sua reformulação enquanto instituição, particularmente sua democratização em um estado democrático de direito (BARBOSA, 2018, p. 62).

Tais características de hierarquia e disciplina não são exclusivas das instituições militares, estando igualmente presentes em sociedades conservadoras, a exemplo da brasileira. Sobre este aspecto:

A política não esteve ausente internamente nas Forças Armadas e na sua história; e foi operacionalizada de várias formas externamente, até mesmo confrontando um paradigma muito exposto, o de que os militares são apolíticos ou não participam da política. Essa reflexão, no entanto, se articula em um segundo eixo a ser desenvolvido sobre uma polêmica questão: hierarquia e disciplina. Esse pressuposto hierárquico não é característica

\footnotetext{
O artigo 10 da Constituição Brasileira de 1891 possuía o seguinte teor: “(...) - A Nação brasileira adota como forma de Governo, sob o regime representativo, a República Federativa, proclamada a 15 de novembro de 1889, e constitui-se, por união perpétua e indissolúvel das suas antigas Províncias, em Estados Unidos do Brasil (...)". Disponível em: http://www.planalto.gov.br/ccivil_03/constituicao/constituicao91.htm. Acesso em: 11 ago. 2019.

Não obstante a Constituição Brasileira, em vários dispositivos, a exemplo do artigo 14, ter fixado um regime democrático participativo, portanto com abertura à maior discussão dos temas por envolvidos, ainda persiste, na mesma carta política, especialmente no tocante às Forças Armadas, cunho estritamente conservador e uma perspectiva de democracia procedimental, a exemplo do artigo 142.
} 
somente de uma instituição militar, na medida em que encontra fundamentos historicamente constituídos numa sociedade conservadora e hierarquizada como a brasileira desde a colonização, mas é um aspecto que passou a ser desafiado com a emergência de movimentos de jovens oficiais e praças, e, por essa razão, recolocado e valorizado institucionalmente ao longo do século XX e XXI (BARBOSA, 2018, p. 22).

O conservadorismo está igualmente atrelado ao receio da participação popular em temas públicos, inclusive os relacionados às Forças Armadas. A atuação da população, quando não negada efetivamente, como no caso do artigo 70 do Decreto 10/1889, é dificultada juridicamente com requisitos mais rígidos e concentração de poder em órgãos estatais ou mesmo faticamente, com desconsideração das pretensões populares por parte das elites políticas.

Como consequência deste conservadorismo, o artigo 142 da Constituição Brasileira coloca como norte da atuação das forças militares a premissa da hierarquia e disciplina, submetendo-as à defesa das instituições com base, portanto, em um viés de democracia procedimental, formal, que se baseia primordialmente na definição das regras do jogo e dos órgãos e agentes incumbidos oficialmente de aplicá-las.

É oportuno neste ponto, para uma discussão inicial ${ }^{8}$, e considerando a necessidade de instituição de um regime democrático que permita uma participação popular deliberativa qualitativa, buscar uma nova compreensão de hierarquia e disciplina não limitada à manutenção de um sistema posto, preconcebido, estático, abstrata e aprioristicamente (democracia procedimental), mas, sim, uma democracia material, que considere as relações sociais e permita uma participação popular deliberativa qualitativa ${ }^{9}$.

No contexto, portanto, desta nova percepção da deliberação qualitativa (FISHKIN, 2015, p. 50), em que argumentos diversos devem ser igualitariamente levados em consideração, analisados efetivamente em seu mérito, com posições conscientes e divergentes de agentes instruídos por fontes plurais de informação, não se pode interpretar a multiplicidade de opiniões nas Forças Armadas como fator negativo, em especial quando originadas de militares de patentes inferiores e, também, com maior razão, advindas de civis.

Neste ponto, a divergência, como a advinda dos militares ditos de "esquerda", no período imediatamente anterior ao golpe de 1964, não poderia ser considerada falta de disciplina ou hierarquia, mas apenas uma discordância democrática institucionalmente desejável, sobremodo como forma de maturação de um regime efetivamente participativo de cidadãos (militares e civis).

Ademais, no que se refere ao outro aspecto e linha igualmente basilar de raciocínio deste artigo, com fundamento na perspectiva diferenciada de direitos humanos (contra-hegemônica) enquanto advindo de um processo constante de resistência e de luta por reconhecimento (HONNETH, 2009, p. 257) das pautas das classes sociais, e não sendo as Forças Armadas agente externo à sociedade, é salutar apontar a releitura dos princípios militares em questão.

Assim, aplicando-se uma visão contra-hegemônica de direitos humanos, os militares não são vistos como meros garantidores de um sistema posto, importador de pautas internacionais influenciadas por agentes políticos e econômicos externos, mas, sim, também com base na soberania nacional material, como membros de uma instituição que tem a função, numa democracia material, de assegurar o direito da população de se manifestar (externar divergências) e lutar pelo reconhecimento de pautas coletivas, inclusive por meio de processos pacíficos de resistência, na adoção de uma filosofia da libertação (DUSSEL, 1995, p. 31); filosofia essa que permite a um povo culturalmente dominado e explorado enxergar a realidade de forma diversa, não atrelada a uma visão externa considerada padrão, ditada prioritariamente por países detentores do poderio financeiro global.

\footnotetext{
8 O presente trabalho não visa a fechar a discussão da temática, mas, apenas, nos limites nele delineados, apontar premissas iniciais para uma reflexão pela comunidade científica.

9 Rememorando as características do regime democrático participativo que garanta uma participação qualitativa: “(...) Podemos falar sobre a qualidade de um processo deliberativo levando em consideração cinco condições: a) Informação: Até que ponto foi disponibilizado aos participantes o acesso a informações razoavelmente precisas que eles acreditam ser relevantes para o assunto; b) Equilíbrio substantivo: Até que ponto os argumentos de um ponto de vista são respondidos por pessoas que têm outro ponto de vista; c) Diversidade: Até que ponto as principais opiniões públicas são representadas por participantes na discussão; d) Consciência: Até que ponto os participantes ponderam o mérito dos argumentos; e) Consideração igualitária: Até que ponto os argumentos oferecidos por todos os participantes são considerados por seus méritos, independente de quais participantes os apresentaram (...)" (FISHKIN, 2015, p. 50).
} 


\section{CONCLUSÃO}

A democracia e os direitos humanos constituem temas que devem ser analisados conjuntamente, porém não de forma abstrata, mas considerando-se situações reais e dinâmicas por meio das quais vão adquirindo uma feição mais concreta.

Não existe um único modelo de democracia, mas uma pluralidade que vai sendo alterada de acordo com a realidade histórica de cada povo. Do mesmo modo, direitos humanos não são abordados numa única visão (hegemônica), mas também sob o prisma diferenciado (contra-hegemônico) que se pauta num processo contínuo e dinâmico de lutas pelo reconhecimento de pautas sociais, de novas formas de enxergar o mundo, notadamente advindas de classes factualmente excluídas.

A cultura democrática brasileira tem, tradicionalmente, adotado um modelo de regime procedimental (formal) que enaltece as instituições e órgãos em detrimento de uma atuação popular. Principalmente sob o advento do sistema constitucional em vigor, entretanto, torna-se imperiosa uma releitura do regime que passou também a ser participativo, buscando-se atingir uma cooperação popular qualitativa (democracia material).

Na mesma direção, caminha a mudança na perspectiva de direitos humanos, com foco maior na comunidade e suas relações concretas de exploração, numa hermenêutica da libertação. Tal alteração de perspectiva torna imperiosa a variação na forma de compreensão de todo o sistema constitucional no qual se insere a instituição militar e, como corolário, seus postulados basilares.

Desta forma, responde-se à problemática posta no sentido de que os princípios base de hierarquia e disciplina podem ser reinterpretados desde que entendidos sob a ótica contra-hegemônica de direitos humanos, na aplicação de uma hermenêutica da libertação e de uma democracia material, que permita uma deliberação qualitativa com efetiva consideração de divergências externas e internas na corporação, sobre os mais diversos temas provindos do seio social.

Aplicando-se, assim, essa visão contra-hegemônica de direitos humanos, os militares não são meros garantidores das regras do jogo (democracia procedimental), mas, sim, asseguradores da instituição e consolidação de um regimento democrático material com deliberações populares qualitativas, e que, consequentemente, observem suas divergências internas e externas (da população) sobre diversos temas sociais e, por resultado, garantam o direito da população de se manifestar (externar divergências) e lutar pelo reconhecimento de pautas coletivas, inclusive por meio de processos pacíficos de resistência.

\section{REFERÊNCIAS}

ARENDT, Hannah. A condição humana. 13. ed. rev. Rio de Janeiro: Forense Universitária, 2017.

BARBOSA, Jefferson Rodrigues (org.). Militares e política no Brasil. São Paulo: Expressão popular, 2018.

BOBBIO, Norberto. O futuro da democracia: uma defesa das regras do jogo. Tradução Marco Aurélio Nogueira. 13. ed. São Paulo: Paz e Terra, 2015.

BRASIL. Lei no 6.880 de 9 de dezembro de 1980. Dispõe sobre o Estatuto dos Militares. Diário oficial da União, Brasília, DF, 11 dez. 1980. Disponível em: http://www.planalto.gov.br/ccivil_03/LEIS/L6880.htm. Acesso em: 19 ago. 2019.

CARVALHO, José Murilo de. Forças Armadas e política no Brasil. São Paulo: Todavia, 2019.

DAHL, Robert A. Sobre a democracia. Tradução Beatriz Sidou. Brasília: Editora Universidade de Brasília, 2016.

DELGADO, Lucilia de Almeida Neves. O governo João Goulart e o golpe de 1964: memória, história e historiografia. Tempo, Niterói, v. 14, n. 28, p. 123-143, jun. 2010. Disponível em: http://www.scielo.br/scielo.php?script=sci_arttext\&pi$\mathrm{d}=$ S1413-077042010000100006\&Ing=en\&nrm=iso. Acesso em: 11 ago. 2019.

DIAMOND, Larry. Para entender a democracia. Tradução Vitor Adriano Liebel et al. Curitiba: Instituto Atuação, 2017.

DUSSEL, Enrique. Filosofia da libertação: crítica à ideologia da exclusão. Tradução Georges I. Maissiat. São Paulo: Paulus, 1995.

FISHKIN, James S. Quando o povo fala: democracia deliberativa e consulta pública. Tradutor Vitor Adriano Liebel. Curitiba: Instituto Atuação, 2015.

FOUCAULT, Michel. Microfísica do poder. 8. ed. Rio de Janeiro: Paz e Terra, 2018.

HONNETH, Axel. Luta por reconhecimento: a gramática moral dos conflitos sociais. Tradução Luiz Repa. São Paulo: Editora 34, 2009.

LASSALLE, Ferdinand. A essência da Constituição. 9. ed. Rio de Janeiro: Freitas Bastos, 2016. 
LIJPHART, Arend. Modelos de democracia: desempenho e padrões de governo em 36 países. Tradução Vera Caputo. 4. ed. Rio de Janeiro: Civilização Brasileira, 2019.

MORGAN, G. Imagens da organização. São Paulo: Atlas, 1996.

PIOVESAN, Flávia. Temas de direitos humanos. 10. ed. São Paulo: Saraiva, 2017.

NEVES, Marcelo. Transconstitucionalismo. São Paulo: Editora WMF Martins Fontes, 2009.

O’DONNELL, Guillermo. Democracia, desenvolvimento humano e direitos humanos. Revista Debates, Porto Alegre, v. 7, n. 1, p. 15-114, 2013.

SEIDL, Ernesto. A formação de um exército à brasileira: lutas corporativas e adaptação institucional. História, Franca, v. 29, n. 2, p. 71-94, dez. 2010. Disponível em: http://www.scielo.br/scielo.php?script=sci_arttext\&pid=S010190742010000200005\&ln$\mathrm{g}=e n \& \mathrm{nrm}=$ iso. Acesso em: 10 ago. 2019.

SILVA, José Afonso da. Curso de Direito Constitucional Positivo. 40. ed. São Paulo: Malheiros, 2016.

SODRÉ, Nelson Werneck. História militar do Brasil. 2. ed. São Paulo: Expressão Popular, 2010.

VITULLO, Gabriel Eduardo. Teorias da democratização e democracia na Argentina contemporânea. Porto Alegre: Editora Sulina, 2007. 